\title{
Determinants of Capital Budgeting Practices and Risks Adjustment among Cambodian Companies
}

\author{
Muhammad M. Ma'aji \\ CamEd Business School, \\ Phnom Pehn, Cambodia \\ Casey Barnett \\ CamEd Business School, \\ Phnom Pehn, Cambodia
}

\begin{abstract}
This study uses a sample survey to analyse the capital budgeting practices of Cambodian companies in the manufacturing sector. The findings show that payback period, NPV, discounted payback period and accounting rate of return are the most popular evaluation techniques. The study also finds that interest rate risk as well as business cycle risk are mainly adjusted with a discount rate, and the commonly used method for calculating cost of capital is the after tax cost of debt and the weighted average cost of capital (WACC). Furthermore, the finding suggests that the longer the existence of a company, the more likely for it to use NPV method. The finding also reveals that the higher the amount of capital investment, the more it is likely to use the NPV method, while the smaller the amount of capital investment, the more likely the payback method will be used. With higher educational background, NPV and ARR are most likely the methods to be used in capital budgeting among the Cambodian firms.
\end{abstract}

Keywords: Capital budgeting, financial management, IRR, NPV, Risk, Payback period, WACC.

\section{INTRODUCTION}

Companies need to invest in wealth-creating assets in order to renew, extend or replace the means by which they carry on their business. Capital investment allows companies to continue to generate cash flows in the future or to maintain the profitability of existing business activities (Watson \& Head, 2010). Financial management is concerned with the planning and controlling, the provision of resources (financing decision), the allocation of resources (investment decision) and finally the control of resources (whether funds are being used effectively or not). This will ultimately lead to achieving the primary objective of financial management, i.e., the maximisation of shareholder wealth. The continuity and sustainability of every company will rely on the returns generated from its investments. According to Miller and Modigliani (1961), future corporate earnings rely on the company's investment policy, and investment decisions are responsible for a company's future profitability and its market value. The capital budgeting theory lies within the concept of shareholders' wealth maximization (Slagmulder et al., 1995) and involves investment decisions in which expenditures and receipts continue over a significant period of time (Peterson \& Fabozzi, 2002; Dayananda et al., 2002).

Investment decisions have significant effects on the long term financial and operational performance of companies and are surrounded with complexity and uncertainty, which present particular challenges to management (Dempsey, 2003). Furthermore, capital investments involve huge capital outflow; it has its unique risks and estimations about the future cash flows. The uncertainty of future cash flows and other estimation difficulties that exist in practice have resulted in the development of various risk analysis and management science techniques to supplement traditional present value-based decision models (Klammer 
et al., 1991). One of the most difficult and intractable issues faced by decision makers and researchers is how to identify, capture and evaluate uncertainties associated with long-term investments. Thus, it requires a rigorous appraisal to weigh its cost and its benefit to the business, as well as its ultimate impact on shareholders wealth, as it requires prediction of future events (Slagmulder, 1997; Abdel-Kader \& Dugdale, 1998). All capital investments involve risk and judgement. A disciplined approach helps management to make rational decisions based on the probable impact of an investment on the future of the business. The presentation of the proposed investment to the decision makers is as important as the process of gathering and evaluating information. The way such a presentation is made often determines the extent to which the appraisal influences the decision.

The main aim of this research is to investigate the prevailing capital budgeting practices when making investment decisions by Cambodian companies. This survey of prevailing capital budgeting practices within Cambodian companies includes the following: (1) examining the capital budgeting methods used in the evaluation of an investment proposal and (2) analysing the risk techniques of capital budgeting used in adjusting risk in investment proposals and (3) determinants of capital budgeting methods among Cambodian companies. During the last two decades, Cambodia experienced a strong economic growth, sustained an average growth rate of 7.6 percent between 1994 to 2015, ranking sixth in the world and the economy is expected to remain strong over the next five years (World Bank, 2017). Cambodia has attained lower middle-income status as of 2015, with gross domestic product (GDP) per capital reaching US $\$ 1,270$, driven by garment exports and tourism. Cambodia has also experienced tremendous amount of business investment not only from local demand, but also heightened foreign interest in investment (Turunen \& Zhou, 2017).

For example, according to statistics from the National Bank of Cambodia (NBC), total trade between Cambodia and the rest of the world in 2016 equalled US\$29 billion, around 161 percent of the country's GDP. Exports from Cambodia reached US $\$ 11$ billion, while imports totalled US $\$ 18$ billion. Foreign direct investment (FDI) into Cambodia increased by 25 percent in 2016 amounting to $\$ 2.15$ billion, most of which were channelled into the financial and manufacturing sectors (Chan, 2017). The investment inflow from foreign countries mostly went to the financial sector, especially to banking, due to the increase in banking institutions' capital reserves and the manufacturing sector. The reasons behind the increasing capital investments are underpinned by peaceful domestic environment, improved investors' confidence, favourable macroeconomic conditions, and increased capacity utilization together with expansion of economic activity (Turunen \& Zhou, 2017). Therefore, nowadays, capital budgeting practices play a significant role than ever before and, to the best of researchers' knowledge, there has not been research on capital budgeting practices in Cambodia. Thus, this research has been designed to investigate prevailing capital budgeting practices in Cambodia.

\section{Defining and understanding capital budgeting}

Different authors define the capital budgeting in different ways. For example, according to O'Sullivan and Sheffrin (2003), 'capital budgeting is the planning process used to assess whether an organization's long term investments such as replacement of machinery, new machinery, new products, new plants and research development projects are worth the funding of cash through the firm's capital resources'. It is the process of allocating resources for major capital, or investment, expenditures. One of the primary goals of capital budgeting investments is to increase the value of the firm to the shareholders (O'Sullivan \& Sheffrin, 2003). Similarly, Dayananda et al. (2002) defined capital budgeting as mainly related to sizable 
investments in long-term assets, which includes either tangible (i.e. property, plant or equipment) or intangible assets (i.e. new technology, trademarks). Regardless of their nature (tangible or intangible), investment projects require careful evaluation as they require very large amounts of cash to be raised and invested, and they will determine whether the company is profitable in the future (Dayananda et al., 2002). Varshney and Maheshwari (2014) both see capital budgeting as a step by step process that businesses use to determine the merits of an investment project. The decision of whether to accept or deny an investment project as part of a company's growth initiatives involves determining the investment rate of return that such a project will generate.

\section{Capital budgeting process}

The specific capital budgeting procedure that a manager uses depends on a manager's level in the organisation, size and complexity of the project being evaluated, and the size of the organisation. Organisations seek to select the best or most profitable investment projects through a carefully designed process, so that they can maximise the return to their shareholders. They also seeks to avoid the negative strategic and financial consequences which could follow from poor investment decisions. The typical steps in the capital budgeting process highlighted by Stowe and Gagne (2018) is shown in Figure 1. However, the capital budgeting process could be dynamic, not static and could be influenced by many changing factors in an organizational environment.

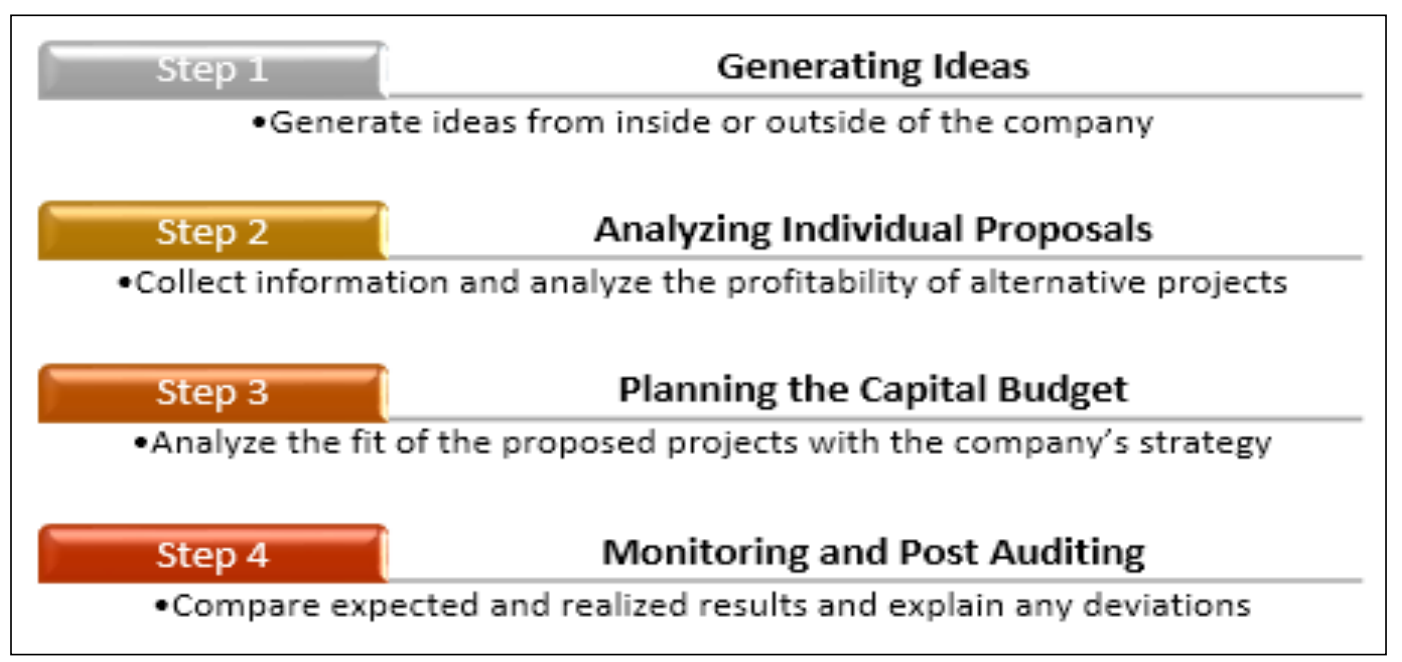

Figure 1. Capital budgeting process adopted from Stowe and Gagne $(2018$, p. 47)

The process starts from generating ideas i.e. to generate a proposal for investments and there could be various reasons for taking up investments in a business. The second step in the process is to analyse the individual proposals i.e. collecting information and selecting all correct criteria to judge the desirability of the proposals. This has to match the objective of the firm to maximize its market value. The third step is to plan the capital budget i.e. organising the profitable proposals into a coordinated whole that fits within the company's overall strategies. Finally, monitoring and post-auditing i.e. involves comparison of actual results with the planned ones. Unfavourable results are identified and analysed; resolving the various difficulties of the projects helps for future selection and execution of the proposals.

\section{Capital budgeting methods/models}

Over the last three decades, significant research has been conducted on capital budgeting practices among companies. However, a review of this literature reveals inconsistent findings: financial managers and academics have not been in full agreement as to the choice of the best capital budgeting method. Therefore, there is no such defined method or model for the 
selection of a proposal for investments as different businesses have different requirements. The literature reveals net present value (NPV), internal rate of return (IRR), modified internal rate of return (MIRR), payback period (PB), discounted payback period (DPB), accounting rate of return (ARR) and profitability index (PI) as the more prevalent capital budgeting methods in today's business world (Elumilade et al., 2006; Maquieira et al., 2012; Ryan \& Ryan, 2002). These capital budgeting methods can be either discounted cash flow (DCF) methods or nonDCF methods. The DCF is an application of the time value of money concept, i.e. the idea that money to be received or paid at some time in the future has less value, today, than an equal amount actually received or paid today. DCF analyses use future free cash flow projections and discounts them, using a required annual rate, to arrive at present value estimates. A present value estimate is then used to evaluate the potential for investment. Non-DCF do not use the concept of time value of money or discount the free cash flow projection. Largely, NPV and IRR are considered DCF methods, and PB and ARR are non-DFC methods.

Early studies generally report DCF models to be the least popular capital budgeting methods. This might be attributed to the lack of financial sophistication and limited use of computer technology in that era. Therefore, payback technique and the ARR as non-DCF were the most preferred methods (Pike, 1996; Schall, Sundam \& Geijsbeek, 1978). However, with the modern financial theory, studies have shown that DCF model have now become the most prepared capital budgeting methods. Arnold and Hatzopoulos (2000) found that practitioners placed greatest emphasis on the discounting techniques (NPV and IRR) with NPV preferred to IRR (97\% of large firms used NPV; 84\% used IRR; 66\% used payback). However, among the DCF methods, through the literature, NPV has trailed IRR in management preference. Managers have argued that the perception of a percentage return is more easily understood and comparable than an absolute dollar value increase in shareholder wealth (Liu \& Stowe, 2005). Therefore, in the past, managers have chosen IRR over NPV. Management view IRR as a more cognitively efficient measure of comparison (Liu \& Stowe, 2005). However, academics have long argued for the superiority of NPV over IRR.

\section{METHODOLOGY}

The study focuses on the manufacturing companies in Cambodia and a self-reported questionnaire has been administered for the collection of data. The manufacturing as well as other industrial sector accounts for 59 percent of the total GDP, while the services sector's contribution to the GDP is 41 percent (World Bank, 2016). The manufacturing sector, especially the garment industry, is the foremost driver of Cambodia's economic activity expansion, thus the selection of the manufacturing sector to be the subject of this study. The questionnaire adopted was originally used and developed in previous studies to facilitate comparison (Elumilade et al., 2006; Graham \& Harvey, 2001; Maquieira et al., 2012; Ryan \& Ryan, 2002; Verma et al., 2009). The structured questionnaire includes closed ended questions inquiring use of discounted/non-discounted and risk-adjusted techniques of capital budgeting, cost of capital calculations, and the capital budgeting process and activities on a Likert scale of 1 to 5 .

A total of 130 questionnaires were distributed to the financial managers/CFOs on the basis that they are most likely to be involved in evaluating investment projects of the company. A covering letter attached to each questionnaire served as an introduction to the purpose of the survey and assured the confidentiality of the information supplied by each respondent. In an attempt to increase the response rate, the questionnaires were presented in-person and appointments were scheduled in advance. Fifty three usable responses were received, given a response rate of 40.8 percent, which is comparable to similar surveys. Data collected were 
presented and analysed using descriptive statistics and inferential statistics (including mean and percentage analysis).

\section{Discussion on participants' characteristics}

\section{ANALYSIS AND DISCUSSION}

The classification of the educational background of the financial managers is presented in Table 1 . Sixty percent $(n=32)$ of managers had undergraduate degree qualification, followed by a 34 percent of them having masters/MBA $(n=18)$. PhD and other qualifications where held by 2 percent $(n=1)$ and 4 percent $(n=2)$, respectively.

Table 1

Educational background

\begin{tabular}{lcc}
\hline Degree & No. of companies & \% \\
\hline PhD & 1 & 1.9 \\
Masters/MBA companies \\
Undergraduate degree & 18 & 34.0 \\
Any other qualification & 32 & 60.3 \\
Total & 2 & 3.8 \\
\hline
\end{tabular}

Source: Survey Data

The sampled companies have been classified in terms of number of years they are in business. The years were classified into 5 categories as shown in Table 2. Based on the respondents' feedback, 47 percent of the companies have been in business for between 10 and 20 years $(\mathrm{n}=$ 25), thirteen companies (25\%) are considered to be newly established businesses that have been operating for less than 10 years. Nineteen percent of the respondents have been in business for between 31 and 40 years, while the remaining 9 percent of the respondents have stayed in business for between 21 and 30 years $(n=5)$.

Table 2

Classification of companies in term of Age

\begin{tabular}{lcc}
\hline Age of Company & No. of companies & \% \\
\hline$<10$ & 13 & 24.5 \\
$10-20$ & 25 & 47.2 \\
$21-30$ & 5 & 9.4 \\
$>30$ & 10 & 18.9 \\
\hline Total & $\mathbf{5 3}$ & $\mathbf{1 0 0 . 0}$
\end{tabular}

\section{Source: Survey Data}

The companies have been classified in terms of size of the capital budgets that they invested. The size of the capital budgets is defined as total annual spending in term of property, plant and equipment (PPE). As shown in Table 3 below, 57 percent of companies' size in terms of their capital budgets is above $\$ 100,000$ but below $\$ 10$ million, while 16 of the companies (accounting for $30 \%$ ) have a capital budget up to $\$ 100,000$. Six companies (representing 11\%) mentioned the size of their capital budget to be between $\$ 10$ million and $\$ 100$ million, while only one company has a capital budget between US $\$ 100$ million to US\$500 million. The reasons behind this huge investment could be as a result of the increased growth witnessed in the manufacturing sector and increased flow of FDI into Cambodia. This will increase the level of intense competition among companies and forcing businesses to invest in modern technological equipment and facilities in order to remain relevant and competitive. 
Table 3

Size of the capital budget

\begin{tabular}{|c|c|c|}
\hline Size of the Capital budget & No. of companies & $\%$ of companies \\
\hline up to $\$ 100,000$ & 16 & 30.2 \\
\hline$<\$ 10$ million & 30 & 56.6 \\
\hline$\$ 10-\$ 100$ million & 6 & 11.3 \\
\hline$\$ 100-\$ 500$ million & 1 & 1.9 \\
\hline$>\$ 500$ million & 0 & 0 \\
\hline Total & 53 & 100 \\
\hline Source: Survey Data & & \\
\hline
\end{tabular}

\section{Purpose of investment for capital budgeting}

Table 4 presents the survey findings on the purpose of investment. Forty seven percent of the respondent $(n=20)$ stated that the dominant motivation for making investment is for expansion into new business and existing business. Moreover, 13 companies (24\%) invest in order to expand existing business. Nine percent of the respondent mentioned that the reason is for equipment replacement and modernization of their operation. Expansion of existing business and equipment replacement is one the reasons of investment as mentioned by 8 percent of the respondents $(n=4)$, while another 8 percent stated that expansion into new business (i.e., diversification) is the motive behind the investment. A majority of the respondents mentioned that expansion into existing business is the main reason for the investment. This could be in the form of increased production capacity, company acquisitions and the introduction of electronically integrated operations, thereby achieving economies of scale, increased sales or product volume to get more income and improve performance of company.

Table 4

Purpose of investment for capital budgeting

\begin{tabular}{lcc}
\hline Purpose of Investment & No. of companies & $\begin{array}{c}\text { \% of } \\
\text { companies }\end{array}$ \\
\hline Expansion into new business/diversification only & 4 & 7.5 \\
Expansion into existing business only & 13 & 24.5 \\
Equipment replacement and modernization only & 5 & 9.4 \\
Expansion into new and existing business only & 25 & 47.2 \\
Expansion of existing business and equipment replacement & 4 & 7.5 \\
Expansion into new business and equipment replacement & 1 & 1.9 \\
Expansion into new business, existing business and & 1 & 1.9 \\
equipment replacement & & 100.0 \\
Total & $\mathbf{5 3}$ & \\
Source: Survey Data & &
\end{tabular}

\section{Factors determining capital budgeting method}

The sample firms were asked about the factors determining the selection of capital budgeting method. Table 5 presents results from their respective managers. The most important factor determining capital budgeting method is top management familiarity (28.3\%). This was followed by the importance of the project (20.8\%), easy and understandability (17\%), experience and competence (13.2\%), finance theory $(11.3 \%)$ and informal rule of thumb with 
just 7.5 percent. Notwithstanding, the remaining factor, i.e. other factors took the mean value less than two which implies "not important" in deciding capital budgeting decision.

Table 5

Factors determining capital budgeting method

\begin{tabular}{lcc}
\hline Factors & $\begin{array}{c}\text { No. of } \\
\text { companies }\end{array}$ & \% of companies \\
\hline Finance theory & 6 & 11.3 \\
Experience and competency & 7 & 13.2 \\
Informal rule of thumb & 4 & 7.5 \\
Importance of the project & 11 & 20.8 \\
Easy and understandability & 9 & 17.0 \\
Top management familiarity & 15 & 28.3 \\
Any other factors & 1 & 1.9 \\
Total & $\mathbf{5 3}$ & $\mathbf{1 0 0 . 0}$ \\
Source: Survey Data & & \\
\hline
\end{tabular}

More so, even though Cambodia is a developing market, the findings show increase awareness and quality of management education. Financial managers are becoming more aware of the decision aids at their disposal and are more than equipped to apply the benefits of information technology explosion.

Table 6

Capital budgeting method

\begin{tabular}{lcc}
\hline Methods & No. of companies & \% of companies \\
\hline Payback (PB) & 18 & 34.0 \\
Discounted Payback (DPB) & 9 & 17.0 \\
Net Present Value (NPV) & 10 & 18.9 \\
Profitability Index (PI) & 3 & 5.7 \\
Modified Internal Rate of Return (MIRR) & 4 & 7.5 \\
Internal Rate of Return (IRR) & 4 & 7.5 \\
Accounting Rate of Return (ARR or ROCE) & 5 & 9.4 \\
Total & $\mathbf{5 3}$ & $\mathbf{1 0 0 . 0}$ \\
Source: Survey Data & & \\
\hline
\end{tabular}

\section{Capital budgeting methods in practice}

The financial managers were asked to respond on which of the financial analysis technique(s) is (are) used in their respective businesses for the appraisal of major investments. According to the respondents, as summarized in Table 6, payback period method (PB) $(n=18)$ is the most important technique used to evaluate investment. This was followed by the net present value $(N P V)$ method $(n=10)$, discounted payback (DPB) $(n=9)$ and accounting rate of return (ARR) or ROCE $(n=5)$. The least likely methods to be employed by the respondent are internal rate of return (IRR) $(n=4)$, modified internal rate of return (MIRR) $(n=4)$ and profitability index (PI) $(n=3)$. The respondent were further asked to indicate which of the capital budgeting method is either used as primary, secondary or neither. Results are presented in Table 7.

Ninety five percent of financial managers reported that PB method is a primary method for capital budgeting, whereas 85 percent of the managers indicated NPV as a primary method. Similarly, 23 percent of the financial managers were reported to use DPB as a primary method, while only 13 percent of the managers used ARR as a primary method. The result also shows 
that the managers preferred to use IRR (79\%), DPB (77\%), PI (64\%) and ARR (34\%) as secondary methods. Furthermore, the result shows that MIRR is neither used as primary nor secondary method. The PB and the NPV methods are reportedly being used as both primary and secondary. Moreover, the survey results also indicate the use of multiple techniques among the companies in Cambodia; some respondents used more than one financial analysis technique when evaluating investment projects (some technique as primary, while others as secondary). This result is consistent with other studies (e.g. Alkaraan \& Northcott, 2006; Arnold \& Hatzopoulos, 2000; Lingesiya, 2015).

Table 7

Capital budgeting methods: primary vs secondary

\begin{tabular}{lccc}
\hline Methods & Primary & Secondary & Neither \\
\hline Payback (PB) & $95 \%(50)$ & $5 \%(3)$ & - \\
Discounted Payback (DPB) & $23 \%(12)$ & $77 \%(41)$ & - \\
Net Present Value (NPV) & $85 \%(45)$ & $15 \%(8)$ & - \\
Profitability Index (PI) & - & $64 \%(34)$ & $36 \%(19)$ \\
Modified Internal Rate of Return (MIRR) & - & - & $100 \%(53)$ \\
Internal Rate of Return (IRR) & - & $79 \%(42)$ & $21 \%(11)$ \\
Accounting Rate of Return (ARR or ROCE) & $13 \%(7)$ & $34 \%(18)$ & $53 \%(28)$ \\
Source: Survey Data & & & \\
\hline
\end{tabular}

Note: Number in parenthesis represents the number of companies.

\section{Estimation of the Cost of Capital}

The respondents were asked to report on how their respective companies derive the discount rate in the appraisal of major capital investments. Table 8 presents information on usage and estimation of the cost of capital. A substantial majority of respondent companies (98\%) used a cost of capital in their investment evaluation techniques, while only about 2 percent of the managers indicated that they do not use cost of capital in their capital budgeting analysis. Results show that cost of debt after tax is the most prevalent method in calculating cost of capital $(n=16)$. The next widely used methods are the weighted average cost of capital (WACC) $(n=12)$, the cost of debt before tax $(n=8)$, cost of equity derived from capital asset pricing model (CAPM) $(n=6)$ and average historical returns $(n=5)$. Cost of equity derived from dividend growth model (DVM) and an arbitrary chosen figure are not popular methods in calculating cost of capital amongst Cambodian companies. The findings highlight that the major source of finance to fund capital investment in Cambodia is through debt finance.

Table 8

Estimation of the Cost of Capital

Methods

No. of companies

$\%$ of companies

Cost of debt before tax

8

15.1

Cost of debt after tax

16

30.2

Cost of equity derived from Dividend Growth model (DVM)

3

5.7

Cost of equity derived from Capital Asset Pricing model (CAPM)

6

11.3

Weighted average cost of capital (WACC)

12

22.6

Average historical returns

5

9.4

An arbitrary chosen figure

2

3.8

None 


\section{Risk factors and adjustments}

Appraising long-term capital investments can be quite challenging to businesses due to the uncertainty surrounding the projects' cash flows. Therefore, risk factors should be considered and adjusted for. Some of this risk factors could be unexpected inflation, interest rate movements, GDP growth or business cycle risk, movement in commodity price and movement in foreign exchange among other factors. The results of the survey as depicted in Table 9 shows that interest rate risk and business cycle risk are mainly adjusted by discount rate (63 and 85 percent, respectively). In contrast, risk of unexpected inflation, foreign exchange risk and commodity price risk are mainly adjusted by cash flows (70, 55 and 94 percent, respectively). Furthermore, risk of unexpected inflation and foreign exchange risk are both adjusted by cost of capital as well as cash flow according to some respondents, while 6 and 10 percent of the respondents neither adjust for risk of commodity price movement and foreign exchange risk respectively.

Table 9

Risk factors and adjustments

\begin{tabular}{lcccc}
\hline Risk Factors & $\begin{array}{c}\text { Adjust cost of } \\
\text { capital }\end{array}$ & $\begin{array}{c}\text { Adjust cash } \\
\text { flow }\end{array}$ & Both & Neither \\
\hline Risk of unexpected inflation & $25 \%(13)$ & $70 \%(37)$ & $5 \%(3)$ & - \\
Interest rate risk & $63 \%(33)$ & $37 \%(20)$ & - & - \\
GDP or business cycle risk & $85 \%(45)$ & $15 \%(8)$ & - & - \\
Commodity price risk & - & $94 \%(50)$ & - & $6 \%(3)$ \\
& $15 \%(8)$ & & $20 \%$ & $10 \%(5)$ \\
Foreign exchange risk & & $55 \%(29)$ & $(11)$ &
\end{tabular}

Source: Survey Data

Note: Number in parenthesis represents the number of companies.

\section{DEVELOPING AND TESTING HYPOTHESES}

The discussion in the previous sub-sections was based on comparing averages. Although the discussion provided some interesting results on the use of capital budgeting methods, in this section, the study goes one step further by performing multivariate regression analysis in order to test hypotheses developed. The objective is to investigate the determinants of capital budgeting methods. In this regards, three hypotheses were developed as follows:

H1. The age of the company affects the selection of capital budgeting methods.

H2. The size of capital budget affects the selection of capital budgeting methods.

H3. The educational qualification of CFO affects the selection of capital budgeting methods.

With respect to the above hypotheses, the study investigated the determinants of four different capital budgeting methods, i.e. the PB, NPV, IRR and ARR methods. The MIRR and PI methods were left out, since the results in Table 6 and 7 showed that the methods were the least preferred method among Cambodian companies.

To test the hypotheses, estimations are carried out using the binary logistic regression method. Binary logistic regression ${ }^{1}$ deals with situations in which the observed outcome for a dependent variable can have only two possible outcome. Using this approach to test the research hypotheses is also applied by Hermes, Smid and Yao (2007).

\footnotetext{
1 To investigate the determinants of capital budgeting method, a logistic regression model of the following form is estimated:

$Z_{i}=\alpha 0+\beta_{1}$ SBUDGETi, $t+\beta_{2}$ EDUCi, $t+\beta_{3}$ AGEi, $t+\mu t$
} 


$$
Z_{i}=\beta^{\prime} x_{i}+u_{i}
$$

The dependent variables $\left(Z_{i}\right)$ are binary dummy variables created as follows: $\mathrm{PB}=1$ if the label value of a firm for the PB method is 4 , it is 0 if the label value of a firm is otherwise; NPV = 1 if the score of a firm for the NPV method is 3 , it is 0 if the label value of a firm is otherwise; IRR = 1 if the label value for a firm for the IRR method is 6, it is 0 if the label value of a firm is otherwise; ARR = 1 if the score of a firm for the ARR method is 7, it is 0 if the label value of a firm is otherwise. The independent variables $\left(x_{i}\right)$ are also binary variables. We have used the following variable specifications: SBUDGET $=1$ if the size of the budget is less than 10 million dollars, it is 0 if the size of the budget is 10 million dollars or more; EDUC $=1$ if the CFO of the firm has a PhD or Master/MBA degree, it is 0 if (s)he has an undergraduate degree; AGE = 1 if the firm is 30 years or older, it is 0 if firm is less than 30 years. $u_{i}=$ error term; $Z_{i}$ ranges from $\alpha$ to $+\alpha$.

The result from the logistic regression is presented in table 10. It shows the result for the determinants of the use of the different capital budgeting techniques. Size of capital budgeting budget (SBUDGET) and educational background of the finance managers (EDUC) are the most influential determinant of capital budgeting method among Cambodian firms. Furthermore, the results show a significant positive coefficient between age of company (AGE) and NPV; and it is statistically significant at the 10 percent level. The finding suggests that the longer the existence of a company, the more likely to use NPV method. Older companies probably have more experience and management capabilities (expertise). Thus, $H 1$ is supported in case of NPV and not supported in case of all other methods (PB, ARR and IRR).

Table 10

Determinants of Capital Budgeting Methods (Logit Analysis)

\begin{tabular}{ccccc}
\hline & PB & NPV & ARR & IRR \\
\hline Constant & $-0.398^{*}$ & $0.544^{* * *}$ & -0.156 & $2.645^{* *}$ \\
SBUDGET & $-1.063^{* * *}$ & $0.345^{* *}$ & -0.432 & 1.200 \\
EDUC & 0.966 & $0.615^{*}$ & $1.429^{* *}$ & -0.159 \\
AGE & -1.155 & $1.258^{*}$ & 1.207 & 1.142 \\
& & & & \\
McFadden R & 0.107 & 0.09 & 0.10 & 0.07 \\
Number of & 53 & 53 & 53 & 53 \\
observations & & & &
\end{tabular}

$*, * *, * * *$ significant at 10 percent, 5 percent and 1 percent levels respectively. The McFadden $\mathrm{R}^{2}$ is an analogue to the $\mathrm{R}^{2}$ reported for regular OLS regression models.

Moreover, the result shows a negative coefficient between SBUDGET and PB which is statistically significant at the 1 percent level. The larger the amount of capital investment, the less likely the PB method will be used. However, there is a positive relation between SBUDGET and NPV. The finding shows that the higher the amount of capital investment, the more likely the NPV method will be used. The variables are statistically significant at the 5 percent level. ARR and IRR are insignificant. The finding is consistent with previous studies where they found that organisations used NPV to appraise project when it involved huge investment (Brounen et al., 2004; Verbeeten, 2006; Hermes et al., 2007). Thus, it can be concluded that $H 2$ was supported in case of NPV and PB, and not supported in case of all other methods.

On the other hand, with higher educational background (EDUC), NPV and ARR are most likely method to be used in capital budgeting. The result shows that EDUC is positively related to 
NPV and ARR and is statistically significant at the 10 percent and 5 percent levels respectively. Financial managers that are highly qualified preferred to use more advanced techniques such as NPV, while non-discounted methods like PB was preferred by less qualified personnel. Graham and Harvey, (2001) and Hermes et al. (2007) argued that managers with higher education have fewer problems in understanding more sophisticated capital budgeting techniques and consequently, they preferred to use them. Thus, $H 3$ is supported in case of NPV and ARR.

\section{CONCLUSION AND IMPLICATIONS}

The capital budgeting practices of a sample of 53 manufacturing companies operating in Cambodia have been investigated. The results revealed that the most important factor determining capital budgeting method are top management familiarity, the importance of the project and experience and competency. PB is the most preferred capital budgeting method, followed NPV, DPB and ARR. Similarly, the study finds that interest rate risk and business cycle risk are mainly adjusted with a discount rate, and the commonly used method for calculating cost of capital was the after tax cost of debt and the WACC. Furthermore, the findings suggest that the longer the existence of a company, the more likely to use NPV method. The finding also revealed that the higher the amount of capital investment, the more likely the NPV method will be used; while the smaller the amount of capital investment, the more likely the PB method will be used. And with higher educational background, NPV and ARR are most likely the methods to be used in capital budgeting.

As far as the world of empirical knowledge is concerned, this is the first study to investigate on capital budgeting practice among Cambodian companies, thus it make a contribution to literature on practices in Cambodia and other frontier markets. The outcome of this study will be useful by practitioners in order for them to understand the prevailing capital budgeting practices at their respective firms. The study highlights the importance of firm's training and improving their skills, as well as understanding and upgrading the competencies of their staff's performance. This is because educational background has significant influence on the selection of capital budgeting method. The outcome of this study also signifies the importance of risk adjustment in capital budgeting decision. Doing so will help the organisation to find out the best technique to maximise shareholders' wealth. In general, this study serves as a foundation for future research.

\section{ACKNOWLEDGEMENT}

This research is fully supported by CamEd Business School, Phnom Pehn Cambodia, therefore the authors wish to express gratitude to CamEd Business School for their financial support.

\section{References}

Abdel-Kader, M.G., \& Dugdale, D., (1998). Investment in advanced manufacturing technology: a study of practice in large U.K. companies. Management Accounting Research 9 (3), 261-284.

Alkaraan, F., \& Northcott, D. (2006). Strategic capital investment decision-making: A role for emergent analysis tools? A study of practice in large UK manufacturing companies. The British Accounting Review, 38, $149-173$.

Arnold, G.C. and Hatzopoulos, P.D. (2000), “The theory-practice gap in capital budgeting: evidence from the United Kingdom", Journal of Business Finance and Accounting, Vol. 10 No. 5, pp. 603-626.

Brounen, D., de Jong, A. and Koedijk, K. (2004), “Corporate finance in Europe: confronting theory with practice”, Financial Management, Vol. 33 No. 4, pp. 71-101.

Chan, S. (2017). FDI up 25 percent. Khmer Times, available at http://www.khmertimeskh.com/news/34577/fdiup-25-/

Dayananda, D., Irons, R., Harrison, S., Herbohn, J. \& Rowland, P. (2002), Capital Budgeting: Financial Appraisal of Investment Projects, Cambridge University Press, Edinburgh. 
Dempsey, M.J., (2003). A multidisciplinary perspective on the evaluation of corporate investment decision making. Accounting, Accountability \& Performance 9 (1), 1-33.

Elumilade, D.O., Asaolu, T.O. \& Ologunde, A.O. (2006). Capital budgeting and economic development in the third world: the case of Nigeria, International Research Journal of Finance and Economics, Vol. 2 No. 2, pp. 136-152.

Graham, J. \& Harvey, C. (2001). The theory and practice of corporate finance: evidence from the field, Journal of Financial Economics, Vol. 60 (2/3), pp. 187-243.

Hermes, N., Smid, P., \& Yao, L. (2007). 2007), “Capital budgeting practices: a comparative study of the Netherlands and China", International Business Review, Vol. 16 No. 5, pp. 630-654.

Klammer, T., Koch, B. \& Wilner, N. (1991), Capital budgeting practice - a survey of corporate use, Journal of Management Accounting Research, Vol. 3 No. 1, pp. 113-130.

Lagmulder, R., Bruggeman, W. \& van Wassenhove, L. (1995). An empirical study of capital budgeting practices for strategic investments in CIM technologies, International Journal of Production Economics, 40(2), 121-152.

Lingesiya, M. N. K. (2015). Capital budgeting practices: evidence from Sri Lanka, Journal of Advances in Management Research, Vol. 12 Iss 1 pp. 55 - 82

Liu, S., \& Stowe, D (2005). The shareholder wealth effects of voluntary foreign delistings: an empirical analysis, Applied Financial Economics Letters, Vol. 1, No. 4, pp. 199-204.

Maquieira, C.P., Preve, L.A. and Allende, V.S. (2012), “Theory and practice of corporate finance: Evidence and distinctive features in Latin America", Emerging Markets Review, Vol. 13 No. 2, pp. 118-148.

Miller, H. \& Modigliani, F. (1961). Dividend policy, growth, and the valuation of shares. The Journal of Business, 34(4), 411-433.

O'Sullivan, A., \& Steven, M. S. (2003). Economics: Principles in action. Upper Saddle River, New Jersey: Pearson Prentice Hall.

Peterson, P.P. \& Fabozzi, F.J. (2002), Capital budgeting: theory and practice, John Wiley \& Sons, 10.

Pike, R. (1996), "A longitudinal survey on capital budgeting practices", Journal of Business financing and Accounting, Vol. 23 No. 1, pp. 79-92.

Ryan, P.A. and Ryan, G.P. (2002), "Capital budgeting practices of the fortune 1,000: how have things changed?", Journal of Business and Management, Vol. 8 No. 4, pp. 355-364.

Schall, L.D., Sundem, G.L. and Geijsbeek, W.R. (1978), "Survey and analysis of capital budgeting methods", The Journal of Finance, Vol. 33 No. 1, pp. 281-287.

Slagmulder, R., Bruggeman, W. \& van Wassenhove, L. (1995), An empirical study of capital budgeting practices for strategic investments in CIM technologies, International Journal of Production Economics, Vol. 40 No. 2, pp. 121152.

Stowe \& Gagne (2018). Corporate finance and portfolio management. CFA Institute.

Turunen, J., \& Zhou, Y. (2017). Cambodia's economy: Growth and challenges, Khmer Times, available at https://www.khmertimeskh.com/5087442/cambodias-economy-growth-challenges/

Varshney, R.L.; K.L. Maheshwari (2010). Manegerial Economics. 23 Daryaganj, New Delhi 110002: Sultan Chand \& Sons.

Verbeeten, F.H.M. (2006), "Do organizations adopt sophisticated capital budgeting practices to deal with uncertainty in the investment decision? A research note", Management Accounting Research, Vol. 17 No. 1, pp. $106-120$.

Verma, S., Gupta, S. \& Batra, R. (2009), A survey of capital budgeting practices in corporate India, The Journal of Business Perspective, Vol. 13 No. 3, pp. 1-17.

Watson, D., \& Head, A. (2010). Corporate finance: Principles and practice. Financial Times Prentice Hall, UK.

World Bank, (2016). Enhancing export competitiveness: The key to Cambodia's future economic success. World Bank Group, available on at http://gs.mef.gov.kh/contents /uploads /2016/10/October-2016-CambodiaEconomic-Update-Oct-10-2016-final.pdf 